\title{
Effect of Hydraulic Oil Entering the Cutting Fluid on the Tool Life and Roughness in Milling of Stainless Steel
}

\author{
Alexey Popov, Robert Schindelarz \\ Department of Machining and Assembly, Faculty of Mechanical Engineering, Technical University of Liberec. \\ 461 17, Studentská 1402/2, Liberec 1, Czech Republic. \\ E-mail: alespopov@yandex.ru,robertschindelarz@seznam.cz
}

The use of cutting fluid increases the tool life and reduces the roughness of the machined surface. However, during the machining the oil from the hydraulic system of the machine often gets into the cutting fluid, which can alter the properties of the cutting fluid. In scientific literature there is no information on the effect of the hydraulic oil entering the cutting fluid on the tool life and roughness. In this regard, at the laboratory of the Department of Machining and Assembly of the Technical University of Liberec, there has been conducted a study to ascertain the effects of hydraulic oil getting into different types of cutting fluids during the milling of stainless steel.

Keywords: Machining, Cutting fluid, Wear

\section{Acknowledgments}

This article is related to the investigation on the Specific University Research Projects which are supported by the Ministry of Education (MSMT) of the Czech Republic.

\section{References}

[1] JERSÁK, J., VRKOSLAVOVÁ, L. (2013). The influence of process fluids on the properties of the surface layer of machined components, Manufacturing Technology, 13(4), pp. 466-473

[2] ROTELlA, G., DILlON JR., O. W., UMBRELlO, D., SETTINERI, L., JAWAHIR, I. S. (2014). The effects of cooling conditions on surface integrity in machining of Ti6Al4V alloy, International Journal of Advanced Manufacturing Technology, 71 (1-4), pp. 47-55

[3] THEPSONTHI, T., HAMDI, M., MITSUI, K. (2009). Investigation into minimal-cutting-fluid application in highspeed milling of hardened steel using carbide mills, International Journal of Machine Tools and Manufacture, 49(2), pp. 156-162

[4] POPOV, A., DUGIN, A. (2013). Study of reasons of increased active force using coolant with uncut chip thickness, The International Journal of Advanced Manufacturing Technology, October, pp.1-8

[5] JERSAK, J., ZIZKA, J. (2015). Essential features of process fluids applied in machining, Manufacturing Techno$\log y, 15$ (6), pp. 985-991

[6] KURAM, E., OZCELIK, B., BAYRAMOGLU, M., DEMIRBAS, E., SIMSEK, B. T. (2013). Optimization of cutting fluids and cutting parameters during end milling by using D-optimal design of experiments, Journal of Cleaner Production, 42, pp. 159-166

[7] POPOV, A, DUGIN, A. (2013). Influence of lubricant and coolant fluid on the cutting force in small-increment planning, Russian Engineering Research, 33(2):84-85

[8] LEDVINA, M., DVORACKOVA, S. (2016). Assesment of the procedural gases influence at turning technology, Manufacturing Technology, 16(1), pp. 162-168

[9] DUGIN, A., JERSAK, J., POPOV, A. (2014). Method for determining of the anti-adhesion ability of cutting fluids, Manufacturing Technology, 14(2), pp. 145-149

[10] DUGIN, A., VOTOCEK, J., POPOV, A. (2014). Method for determining the tribological properties of the cutting fluid, Manufacturing Technology, 14(2), pp. 149-153

[11] BAKAlOVA, T., SVOBODOVA, L., BORUVKOVA, K., LOUDA, P., VOLESKY, L. (2016). The influence of nanoadditives on the tribological properties of process fluids, Journal of Physics: Conference Series 709 (1), 012001 